\title{
Vektloddene fra Hamarkaupangen - en studie av middelalderens vektloddtyper og preg
}

\begin{abstract}
The contents of 313 weights found at the medieval diocese in Hamarkaupangen provides a rare opportunity to introduce a rich amount of weight categories and their ornaments, found in a medieval setting. The study introduces the weight types and the weight system found in the collection, but deals mainly with the use of an ornamented gothic minuscule h, found on 78 out of 313 weights. Four different methods have been used to create this motif. Two out of four methods, representing nearly $30 \%$ of the weights, are well-suited for mass production. The similarities between the ornament $\mathrm{h}$, found on both medieval Norwegian coins and weights, indicate that the coin ornament $h$ has been copied, when hand engraved, on nearly $70 \%$ of the 78 weights. This research implies that the ornament $\mathrm{h}$ found on weights can be related to the only Norwegian king who used exactly this symbol as his monogram, Håkon V. Magnusson (1299-1319). King Håkon V was well known for his efforts to control the standard of weights and coins in Norway. His monogram is also present on one of the blacksmith's tools found in Hamarkaupangen. This may point in the direction of a well-organized, official plan for adjusting weights.
\end{abstract}

\section{Innledning}

I det arkeologiske materialet fra Hamarkaupangen finnes en stor mengde vektlodd fra middelalderen. Både antallet funn og det rike innholdet av vektloddtyper, preg og dekor gjør samlingen uvanlig sammenliknet med øvrige vektloddfunn fra norsk middelalder. Selv om gjenstandenes funksjon som veieredskap er videreført fra vikingtid til middelalder, tyder de mange pregene på at vektlodd kan ha fått en ny rolle i middelalderen. Vektloddene knyttes til det minste av tre veieredskaper fra middelalderen, skålvekten. I motsetning til bismervekten og jernpunderen, som veide opp varer med større volum og vekt, kunne skålvekten med stor presisjon veie opp små varemengder med lav vekt og lite volum (KHLNM 1982:19:634-636; Sperber 1996:24, 116; Pedersen 2000:73-75). Skålvekten er en balansevekt i metall (figur 1). Den består av to små metallskåler (a) som henger fra lenker i hver ende av en vektarm (b), som balanserer om en akse. Midt på vektarmen er det en nål (c). Det man ville veie, ble lagt i den ene skålen, mens vektlodd ble lagt i den andre. Når de to skålene inneholdt like mye vekt, var skålvekten i balanse, og nålen pekte loddrett opp. Skålvekt og vektlodd kunne brukes både til addisjon og subtraksjon. Det ble tidlig avklart at vektlodd og skålvekt ikke ble brukt til å veie opp varene som handelen dreide seg om, men betalings- 


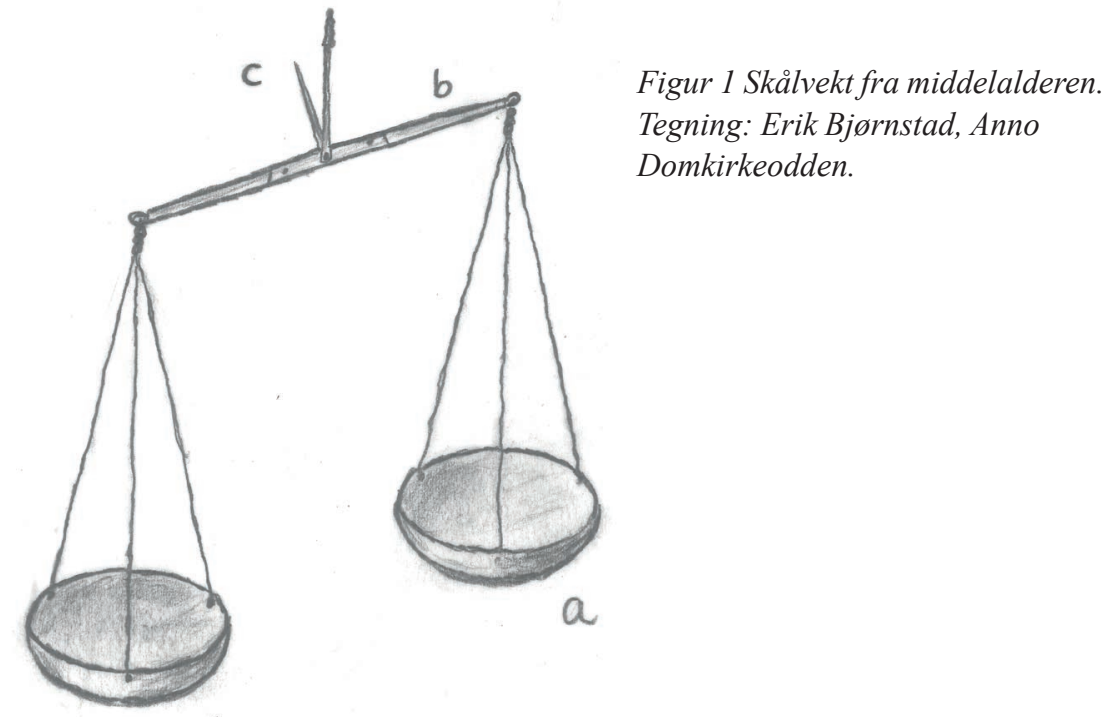

midlene (Petersen 1934:42; Brøgger 1936:77). Vektredskapene kunne også tilhøre andre enn handelsmenn (Petersen 1934:43). Vektloddfunn fra utgravninger i Birka, Helgö, Uppåkra, Ribe og Kaupang bekrefter en forbindelse mellom vektutstyr og metallhåndverk allerede før vikingtid (Kyhlberg 1973, 1980a, 1980b; Gustin 1997; Pedersen 2000, 2008).

Vektlodd fra middelalderen er ikke uvanlige. Ofte dukker de opp som enkeltfunn ved arkeologiske utgravninger i middelalderbyene, men også på andre møteplasser. Det er registrert 523 vektlodd fra middelalderen ved universitetsmuseene i Norge (Unimus 2019). Vektloddene fra Hamarkaupangen er løsfunn som geografisk er tilknyttet Hamarkaupangen, hvor Hamar bispesete lå i perioden 1152-1537. Denne samlingen er i dag ikke inkludert i oversikten fra Unimus. Innenfor hver vektloddtype fra Hamarkaupangen finnes det gjenstander med et preg som viser at de har blitt brukt i middelalderen. Likevel kan enkelte av vektloddtypene ha sin opprinnelse i vikingtid. Vektloddene befinner seg i museet Domkirkeoddens samlinger og består av 313 gjenstander. Det er kjent at det finnes to andre vektlodd fra Hamarkaupangen, som oppbevares ved Oldsakssamlingen i Oslo. De er registrert i Unimus (kulevektlodd C35621, sylindervektlodd C36200), men inngår ikke i min studie av vektloddmaterialet fra Hamarkaupangen.

Forskningen på vektlodd i Skandinavia har tilnærmet ensidig dreid seg om vikingtidens vektlodd, deres funksjon og rolle, typologi og vektstandard (Brøgger 1921; Petersen 1934; Steinnes 1936; Kyhlberg 1973, 1980a, 1980b; Sperber 1996; Gustin 1997; Steuer 1997; Pedersen 2000, 2008, 2010). Studiene av preg har hatt størst fokus på vikingtidens vektlodd, der de mest alminnelige pregene er punslede punkter. De opptrer spesielt på kulevektlodd med to flate poler samt på kubooktaedriske vektlodd, altså lodd med en terningform der alle hjørner er kuttet slik at gjenstanden får 12 hjørner og 14 sideflater. Preget av punslede punkter er primært tolket som symbol for vektverdi (Brøgger 1921; Sperber 1997; Pedersen 2000). Preg som etterlikner arabisk skrift, har også utløst en debatt om opphav (Mikkelsen 1996; Sperber 1996; Gustin 1997; Pedersen 2000).

Det er forsket lite på de mange vektloddfunnene fra middelalderen. Vektlodd fra denne perioden viser en større variasjon i preg, og det brukes hovedsakelig andre typer symboler 


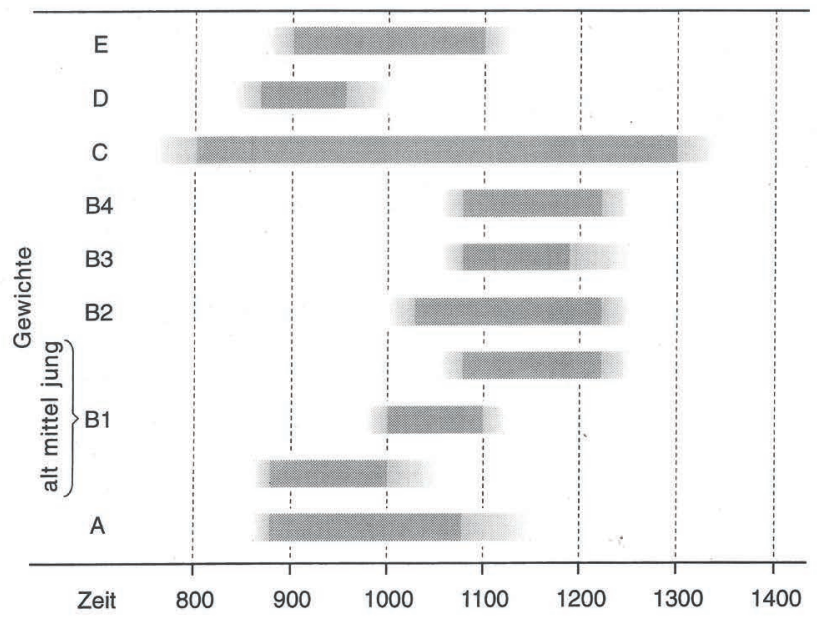

Figur 2 Steuers vektloddskronologi: A= kubooktaedriske vektlodd, B=kuleformede vektlodd, $C=$ ulike typer blyvektlodd, $D=$ vektlodd med kjerne av bly og kappe av kobberlegering eller emaljering, E= ulike gjenstander med vekt og funksjon som vektlodd, eksempelvis endestykker på ringspenner. Kilde: Heiko Steuer 1997:320.

enn dem vi finner på vikingtidens vektlodd. Bokstavpreg er en av flere symboltyper. Preget av bokstaven gotisk minuskel h på hesteformede vektlodd har blitt diskutert av Christopher Andreas Holmboe (1863), Anton Wilhelm Brøgger (1921) og Sigurd Grieg (1933). Forøvrig har vektlodd vært sentrale i debatten omkring middelalderens vektstandard (Brøgger 1921; Steinnes 1936:89; Steuer 1997:11-12; Pedersen 2000:19). Gjenstandenes typologi og kronologi i middelalderen er ikke berørt, ut over at Heiko Steuer (1997) har videreført typologi og kronologi for vikingtidens vektlodd i Nord-Europa og Skandinavia opp til 1300-tallet (figur 2).

Vektloddmaterialet fra middelalderen er et kildemateriale som fortjener større oppmerksomhet. Mitt bidrag til forskningen på middelaldernes vektlodd vil være en presentasjon av Hamarkaupangens vektloddsamling. I tillegg vil jeg ta opp igjen tråden fra diskusjonen om preget gotisk minuskel $\mathrm{h}$, ettersom dette bokstavpreget finnes på mange av vektloddene $\mathrm{i}$ samlingen. Jeg vil undersøke om preget av h på vektlodd kan knyttes til en av de norske middelalderkongene som brukte symbolet h som monogram.

Artikkelen er todelt. Først presenteres vektloddene fra Hamarkaupangen og deres typologi, materiale og vekt. Deretter vil jeg diskutere forekomsten av preget gotisk minuskel h på vektloddene og diskutere den i lys av preg på middelalderens mynter. Jeg vil sette undersøkelsen inn i en historisk kontekst ved å undersøke om skriftlige kilder kan bidra til å identifisere betydningen av preget $\mathrm{h}$ på vektlodd. For å få et komparativt grunnlag for Hamarkaupangens vektlodd trekker jeg inn vektlodd fra middelalderen i Oslo, oppbevart ved Kulturhistorisk museum (KHM) og fra Trondheim ved Vitenskapsmuseet (VM). Den sistnevnte samlingen har jeg fått mulighet til å studere. Formålet er å undersøke hvordan vektloddtyper og preg fra Hamarkaupangen relaterer seg til vektloddfunn fra andre middelalderbyer. 


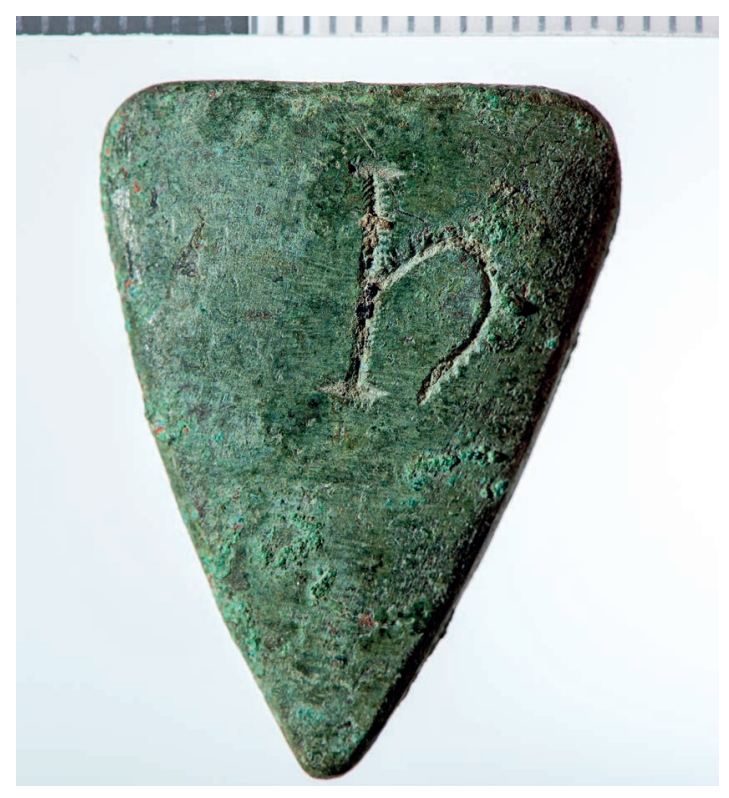

Bilde 1 Skjoldformet vektlodd med preg av en gotisk minuskel $h$. Gjenstand HKH-13145. Foto: G.O.A. Anno Domkirkeodden.

\section{Hamarkaupangens vektlodd: typer, materiale og vekt}

Vektloddsamlingen fra Hamarkaupangen fordeler seg på ti typer (diagram 1). Majoriteten av gjenstandstypene er også kjent fra andre funn. Vektlodd av typen kuler med to flate poler, samt segment-, konisk-, sylinder- og prismeformede finnes i vikingtid, sammen med plateformede vektlodd av bly. Disse er blant annet funnet på Kaupang (Pedersen 2008:120-124). I den grad Steuers vektloddkronologi kan relateres til vektlodd fra Hamarkaupangen, gjelder det hovedsakelig kuleformede vektlodd i kobberlegering med to poler (Steuer type B)

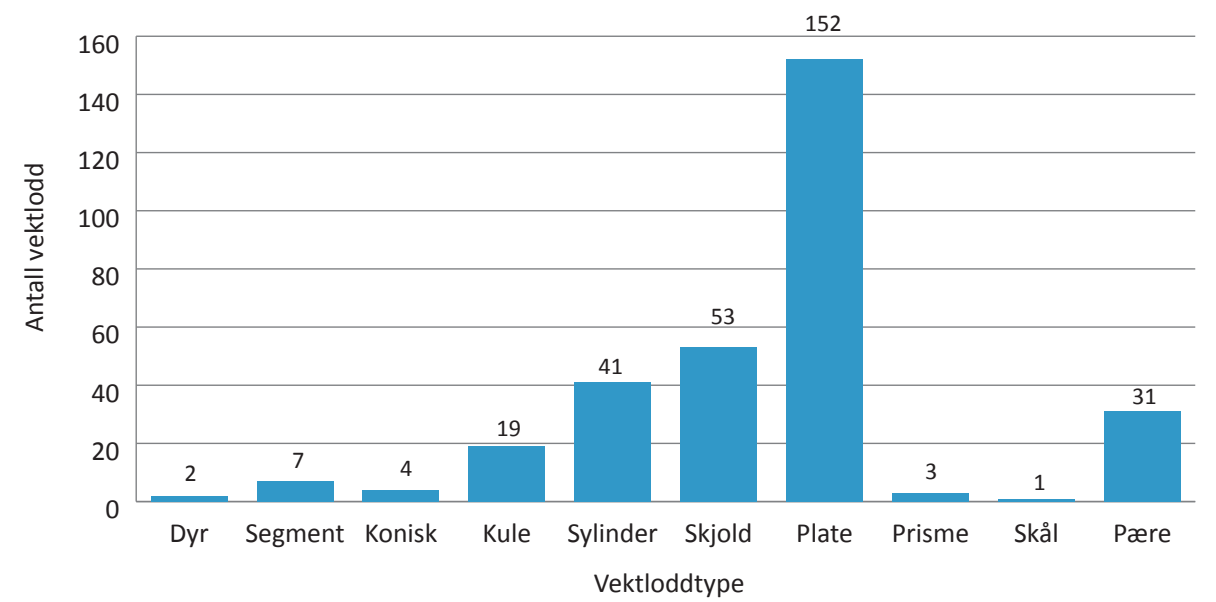

Diagram 1 Typologisk fordeling av vektlodd fra Hamarkaupangen. Statistikk: A.K. Bakstad 2019. 
samt ulike typer blyvektlodd (Steuer type C). Steuers oversikt (figur 2) viser at vikingtidens kulevektlodd av kobberlegering går ut av produksjon på 1200-tallet, mens variantene av blyvektlodd fra vikingtid fortsatt er i bruk på 1300-tallet. Fraværet av kubooktaedriske vektlodd og det at fire av totalt 19 kulevektlodd kan knyttes til Steuers kulevektloddtyper B2 og B4 (HKH-05531, HKH-13785 og HKH-07328, HKH-13234), antyder at vektloddsamlingen kan ha sitt hovedtyngdepunkt på 1100-tallet. Vektlodd formet som dyr og skjold, platelodd i kobberlegering samt skål- og pærevektlodd kan dateres til middelalderen. Samlingene ved KHM inkluderer pærevektlodd og dyreformede lodd, som hestevektlodd (Grieg 1933: figur 324, 331). Disse vektloddtypene finnes også i Vitenskapsmuseet samlinger (T27579, T27619) i tillegg til skålformede vektlodd (T5267). Plate- og skjoldformede vektlodd i kobberlegering er ikke representert i Vitenskapsmuseets samlinger (selvstudium, Vitenskapsmuseet, Trondheim 28.-29. oktober 2016). Et mulig platelodd i kobberlegering fra Tønsberg (C36204) finnes ved KHM. Det er ukjent om det kan finnes flere slike vektlodd ved KHM, men i så fall er de ikke registrert som vektlodd. De flate, tynne og små platevektloddene kan ofte forveksles med plateavklipp eller plateemner, mens skjoldvektloddene med sin særegne, buede utforming er noe enklere å identifisere. Jeg har dessverre ikke fått tilgang til vektloddmaterialet fra Oslo på grunn av KHMs flytteplaner og revisjon. Gjennomgangen av vektloddene fra Trondheim og inntrykket av vektloddtypene fra Oslo gjennom databasen Unimus kan tyde på at den store mengden plate- og skjoldvektlodd i kobberlegering som er funnet i Hamarkaupangen, skiller seg ut fra funnene kjent fra middelalderbyene Oslo og Trondheim. Det er forøvrig ukjent om museene kan ha denne type gjenstander uten at de er blitt katalogisert som vektlodd.

Alle vektloddene er laget i metall (diagram 2). De er enten støpt eller blitt laget av hamrede metallplater der gjenstandene er blitt klippet ut. En majoritet på 258 vektlodd, 82,4 \%, er laget i en kobberlegering. Her har jeg også valgt å inkludere tre vektlodd i kobberlegering med en kjerne av bly, 13 med rest av forsølving samt ett med rest av forgylling. Den andre hovedgruppen er i bly og består av 52 gjenstander, 16,6 \% av samlingen. Gruppen har ingen

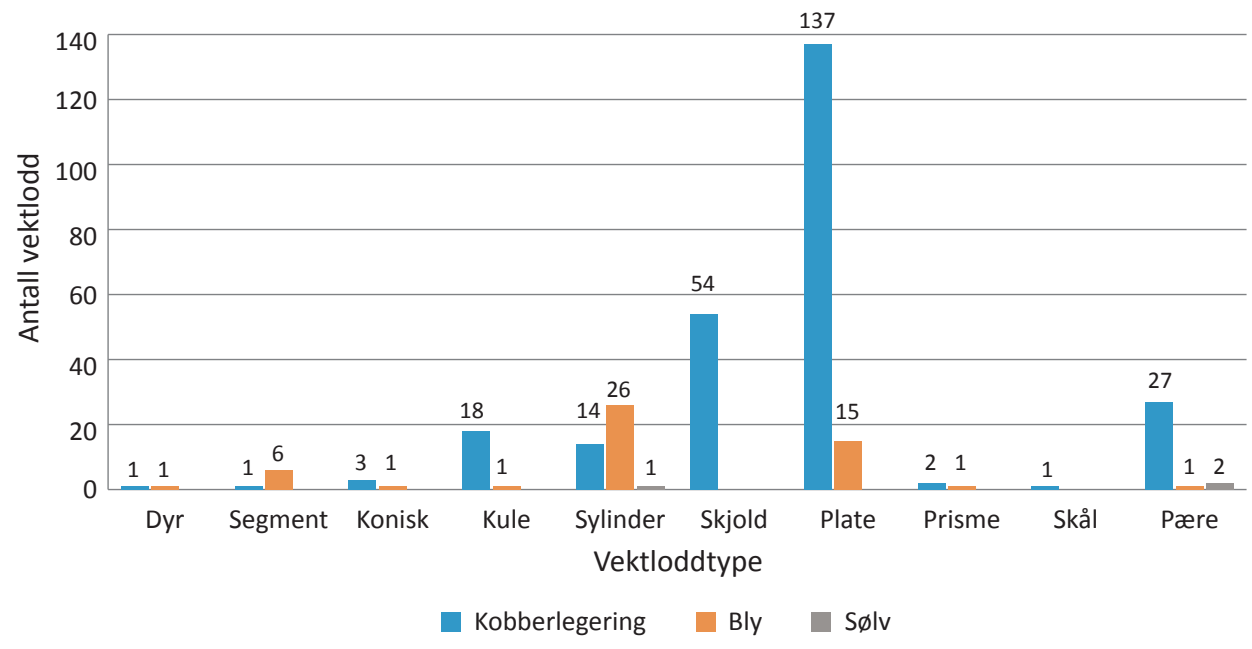

Diagram 2 Vektlodd fordelt etter kategori og metallinnhold. Statistikk: A.K. Bakstad 2019. 


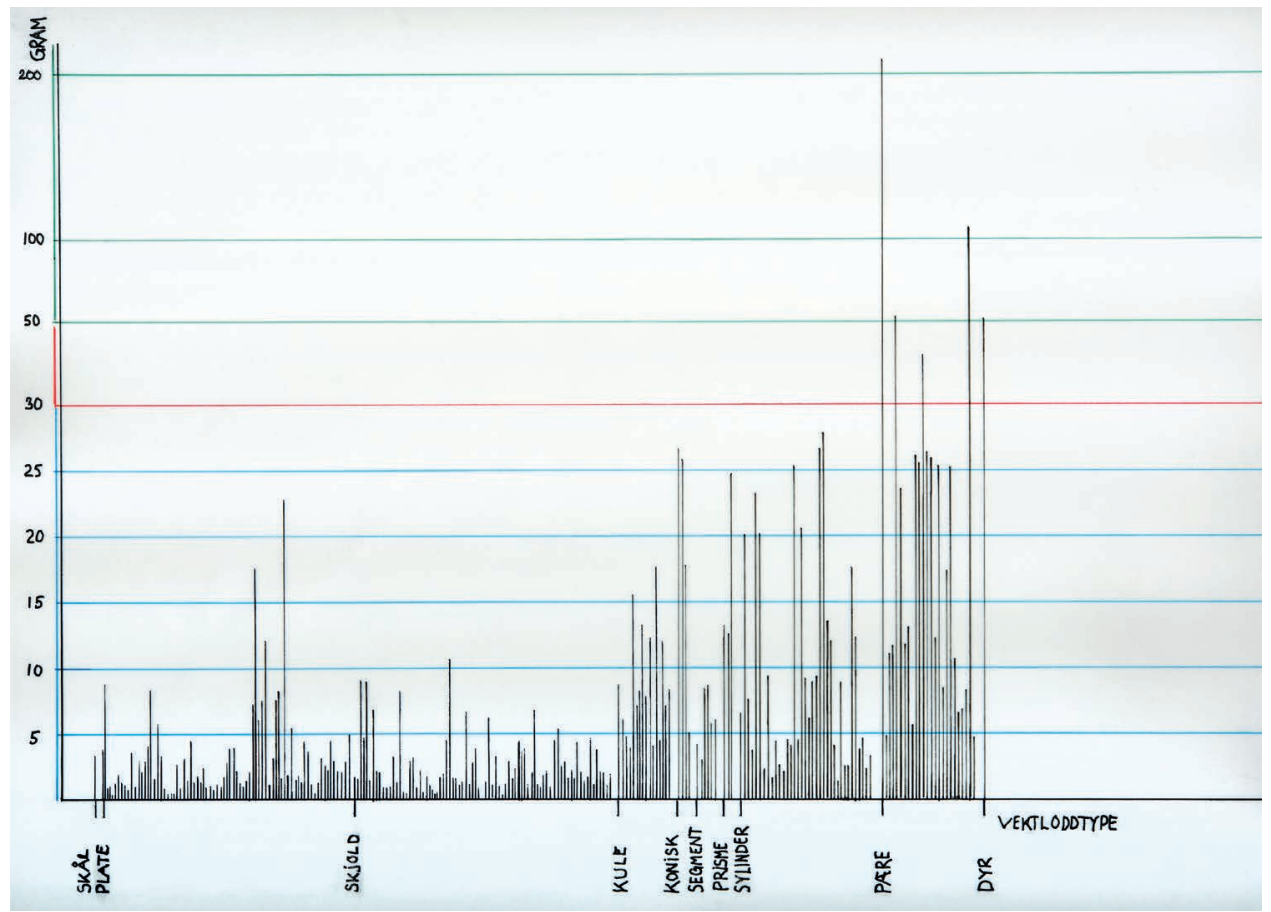

Diagram 3 Komplette vektlodd fordelt etter vektloddtype og vekt. Den vertikale aksen er inndelt i tre fargekoder som symboliserer bruk av tre ulike målestokker. Det er gjort for at vekten til små og store vektlodd skal vare lesbare. Tegning: Erik Bjørnstad, Anno

Domkirkeodden. Statistikk: A.K. Bakstad 2019.

tegn til sekundær metalltype. Den siste gruppen består av tre vektlodd i sølv, nær $1 \%$ av samlingen. Her har jeg valgt å inkludere to pærevektlodd i sølv med en kjerne av bly, samt et sylinderlodd som er komplett i sølv. Kobberlegering er representert i alle de 10 vektloddtypene. Dette er det enerådende materialet blant skjoldvektlodd, mens hele $90,1 \%$ av plateloddene, $90 \%$ av pæreloddene og 94,7\% av kuleloddene er i kobberlegering. Vektlodd i bly er representert i 8 av 10 vektloddkategorier. De to kategoriene segmentlodd og sylinderlodd har prosentvis flest blyvektlodd, med henholdsvis 85,7\% og 63,4\%, mens skålformede vektlodd og skjoldvektlodd ikke inneholder blygjenstander.

Vektloddene fra Hamarkaupangen er relativt godt bevart. Av 313 gjenstander har 248 en tilnærmet komplett form, i betydning av å være uten skader. De er dermed egnet for en vurdering av opprinnelig vekt (diagram 3). Gjenstandenes vekt varierer mellom 0,34 og 209 gram. De mest tallrike typene, plater og skjold, utmerker seg ved å inneholde henholdsvis $35,9 \%$ og 29,9 \% synlig skadde vektlodd. Den høye skadeprosenten kan ha sammenheng med at gjenstandene er bearbeidede, tynne kobberplater som er ekstra utsatt for skade ved opphold i jorda. Vektfordelingen til de komplette vektloddene vil bære preg av at de har noe slitasje. 
Formålet med å veie de komplette vektloddene er å undersøke i hvilken grad kjente vektenheter fra middelalderen, som mark, øre og ertog, kan være representert i vektloddsamlingen. Ettersom en stor majoritet av Hamarkaupangens vektlodd ikke har noen nærmere datering, kan samlingen inneholde vektlodd både fra sen vikingtid og middelalder. Samlingen kan dermed inneholde gjenstander som representerer vektstandarder fra begge periodene. Middelalderens vektstandard tok utgangspunkt i enheten mark, som kunne deles i åtte øre og de igjen i tre ertoger. Brøgger (1921:5-12, 80-85) kom fram til at man i eldre jernalder hadde en øre på 26,88 gram, som i vikingtid ble supplert med en «yngre» øre på 24,59 gram. Ørens vekt har vært undersøkt av flere (Brøgger 1921:95; Steinnes 1936:91), men som Unn Pedersen (2000:19) har påpekt, har alle studier vist at middelalderens øre ligger tett opp mot Brøggers eldre øre på 26,88 gram. Det er påvist at vektlodd var nøye kalibrert i forhold til øvrige lodd i samme vektloddsett, men at gjenstander som skulle representere samme vektverdi, eksempelvis øren, kunne avvike med opp mot 3 gram fra et vektloddsett til et annet (Brøgger 1921:77-85; Pedersen 2000:75-77). Sammen med slitasje og korrosjon bidrar det til en forventet variasjon i vektenhetene.

En gjennomgang av de komplette vektloddenes vektverdi viser at deres gjennomsnittsvekt er 7,5 gram. Dette tallet øker kraftig, særlig fordi et vektlodd på 209 gram høyner gjennomsnittsvekten for samlingen. Et bedre redskap til å forstå vektloddsamlingens middelvekt kan derfor være medianvekten, som er det tallet man får når man setter opp alle vektverdiene i rekkefølgen fra det letteste til det tyngste loddet, og tar summen av de to vektverdiene i midten av skalaen og deler på to. Medianvekten for komplette vektlodd fra Hamarkaupangen er 3,32 gram. Medianvekten antyder i dette tilfellet i større grad enn gjennomsnittsvekten hvordan vektloddsamlingens vektverdier fordeler seg.

Blant de 248 komplette vektloddene har 140 lodd en vekt mellom 0,32 og 3,89 gram (diagram 3). Det betyr at 56,5\% av de komplette vektloddene fra Hamarkaupangen representerer vektverdier under 4 gram. Gruppen av vektlodd innenfor 5, 6 og 7 gram er representert med henholdsvis 9, 8 og 7 gjenstander. Det finnes 13 komplette vektlodd med en vektverdi innenfor 8 gram. I de følgende vektverdiene er det spesielt to som skiller seg ut med et høyere antall gjenstander, vektlodd på 12 og 25 gram, der begge vektverdiene inneholder 7 vektlodd hver. Konsentrasjonen av vektlodd rundt vektverdiene 25, 12 og 8 gram antyder at disse vektloddene kan representere vektverdier som ørevektlodd, halvøres vektlodd og ørens tredeling, ertog. De tre vektloddene med en vektverdi mellom 48 og 52 gram kan representere toøres vektlodd, mens de to vektloddene på henholdsvis 107 og 209 gram kan være representanter for en halv og en hel mark.

\section{Preg}

Det er observert tegn til preg på 288 av 313 vektlodd. Mer enn $90 \%$ av vektloddene i samlingen kan dermed ha hatt preg. Varierende bevaringsgrad og slitasje på overflatene har betydning for identifikasjonen av pregene, og det har ikke blitt utført noen teknisk materialanalyse ut over visuelle studier med mikroskop. Bevaringstilstanden til hvert preg er kategorisert i ett av fire nivåer: «usikker» om preg med lav synlighet og sannsynlighet, «sannsynlig» for synlig preg med noe usikker karakter, i kategorien «svært sannsynlig» er preget godt nok til å utelukke andre utforminger, mens «sikker» betyr at preget har en klar utforming. Det finnes sikre preg på gjenstander i alle ti vektloddtyper, og de opptrer i mange 


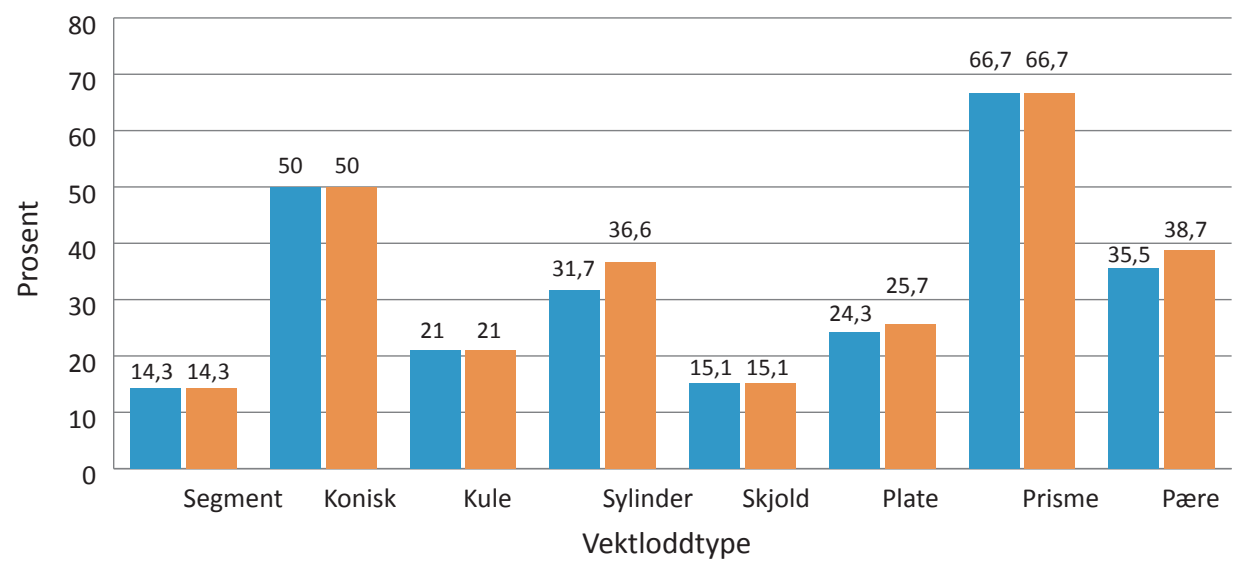

antall vektlodd med preg pr.kategori i \% Antall utførte preg av $\mathrm{h}$ pr kategori i \%

Diagram 4 Typologisk fordeling av preget gotisk minuskel hi \%. Statistikk: A.K. Bakstad 2019.

varianter. En variant er bokstavpreg, som gotisk minuskel h, gotisk majuskel A og utgaver av gotisk majuskel $\mathrm{O}$ og B. I tillegg finnes figurpreg som hammer, krone, kors, oval, motiver av konger og helgener, fugler, blomster, stjerner, kranser, våpenskjold og punslede punkter.

Preget av gotisk minuskel h skiller seg ut ved at 8 av 10 vektloddtyper i samlingen har sikre utgaver av dette preget. 78 av 313 gjenstander har svært sannsynlige og sikre preg av en h. Det er kun vektloddtypene dyr og skål, totalt tre gjenstander, som ikke har dette preget. Symbolet opptrer følgelig på en stor andel av gjenstandene, totalt har 32,2\% av vektloddene i de åtte kategoriene dette preget.

I diagram 4 vises forekomsten av preget gotisk minuskel h i de ulike vektloddtypene fra Hamarkaupangen. Blant vektloddtyper med mer enn 10 lodd finnes en spesielt høy representasjon av preget h blant plate-, sylinder- og pærevektlodd. I fem tilfeller har lodd fått to slike preg, henholdsvis to platelodd, to sylinderlodd og et pærevektlodd (HKH-13455, HKH-13636, HKH-04030, HKH-13460, HKH-13636). Imidlertid er ingen av h-pregene på samme gjenstand identisk utført.

Den gotiske minuskel h opptrer på vektloddene både alene i 37 tilfeller og i 41 tilfeller i kombinasjon med andre preg. I 15 av 78 tilfeller sees en h sammen med et hammersymbol. På seks av 78 vektlodd finnes en preget h og en krone. Hammeren er et håndverkersymbol for smeder og laug som går tilbake til middelalderen (Huitfeldt-Kaas 1899:1:15 nr. 199), mens kronepreget er et offentlig symbol knyttet til kongemakten, som ofte sees på middelalderens mynter (Skaare 1995:30, 32, 34).

Preget av $\mathrm{h}$ ble ikke påvist ved min gjennomgang av vektloddene fra bygravninger $\mathrm{i}$ Trondheim. Publiserte arkeologiske byfunn fra Oslo ser ikke ut til å omfatte vektlodd med preg av h. Imidlertid er vektloddfunn med dette preget kjent fra store deler av landet ellers (Unimus: Nes, Akershus: C59138; Vestby: C55758, Sunndal: T27289, T27279; Levanger: T27619; Midtre Gauldal: T27649; Ørlandet: T27901). Vektlodd med preg av h er derfor 
ikke uvanlige, men antallet vektlodd med dette preget i Hamarkaupangen er påfallende stort.

\section{Hva betyr gotisk minuskel h?}

Middelalderens mynter inneholder symboler som kan knyttes til den enkelte konges myndighet og regjeringstid (Ahlström mfl. 1976:19-49; Skaare 1997:2:19-41). Eksempler er kongenes initialer, monogram eller kronestempel. Disse pregene hadde en fast betydning, og kunne bare distribueres på vegne av den regjerende kongen (Skaare 1997:2:182-207). Pregene på middelalderens mynter hadde derfor en fast betydning og en offentlig rolle (Ramberg 2017:25, 253, 256). Symbolenes verdi lå nettopp i at de kunne gjenkjennes av alle som så dem, slik at utsteder og meningsinnhold kunne identifiseres. Det er derfor grunn til å anta at et preg måtte bety det samme uansett hvor det ble plassert. Imidlertid kan endringer i selve symbolet ha åpnet for en endret betydning. Eksempelvis regnes både majuskel O og A som symboler for Oslo/Asloensis (Skaare 1995:1:82), mens symbolet av en kronet gotisk O representerer monogrammet til Olav 4. Håkonsson, som var konge fra 1380 til 1387 (Skaare 1995:2: nr. 277, 278).

I den norske kongerekken finner vi tre konger i middelalderen som bruker preget av en gotisk minuskel h. Håkon 5. Magnusson (1299-1319) var den første som brukte h som monogram. Ofte sees en prikk plassert mellom beina til h-en, og i noen tilfeller finnes en variant med en liten gotisk minuskel m (Skaare 1995:2: nr. 244, 253 og nr. 250, 252). Håkon 6. Magnussons (1355-1380) monogram er også en h, men den har en krone (Skaare 1995:2: nr. 275, 276). Det samme gjelder monogrammet til kong Hans (1483-1513), som også er en kronet h (Skaare 1995:2: nr. 294). Disse to kongenes monogrammer skiller seg hovedsakelig fra hverandre ved at kong Hans bruker en omskrift langs myntens ytterkant, legenden, som klargjør myntenes proveniens (Skaare 1995:2: nr. 294-297), mens myntene fra Håkon 6. kun opptrer med en kronet h (Skaare 1995:2: nr. 275, 276).

Numismatikeren Christopher A. Holmboe omtalte i 1863 preget av en gotisk minuskel h på en rekke dyre- og hesteformede gjenstander i kobberlegering. Han identifiserte gjenstan-

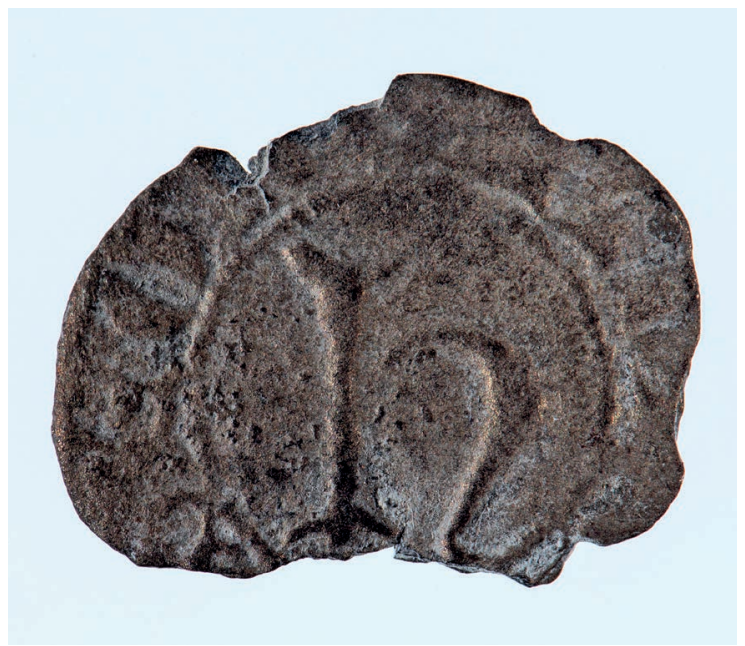

Bilde 2 Kong Håkon 5. Magnussons monogram på en penning. Gjenstand HKH-14053. Foto: G.O.A. Anno Domkirkeodden. 
dene som vektlodd på grunnlag av deres vekt, og daterte dem på bakgrunn av deres preg av h og $\mathrm{o}$, som han mente hadde en fullkommen likhet med initialene man finner på mynter fra 1300-tallets konger Håkon 5., Håkon 6. og Olav 4. (Holmboe 1863:67-78). Senere mente Brøgger (1921:91) at preget av h måtte være et kongelig justermerke som representerte kong Håkon 5. Han påpekte at 47 av 53 vektlodd var funnet i eller rundt Oslo, der Håkon 5 . hadde hatt sete, og at rettarbøter fra Håkons hertugtid synliggjorde at han var opptatt av vektstandarden (Brøgger 1921:92). Grieg (1933:372-374) foreslo på sin side at et platevektlodd fra Domkirkeodden med preget h (Grieg 1933: nr. 327) kunne bety at h symboliserte Hamar, «liksom på mynter» (Grieg 1933:373). Funnet av et vektlodd på Ski med identisk preg av h som vektloddet fra Hamar (Brøgger 1921: figur 49) gjorde sitt til at Grieg likevel sluttet seg til Brøggers påstand om at preget h måtte være kong Håkon 5.s initial (Grieg 1933:373). Siden har gruppen av hesteformede vektlodd blitt kalt «Håkon 5.s messinghester».

Håkon Magnusson var myndig fra 1264, hertug fra 1273 og norsk konge fra 1299 til sin død i 1319. Som Brøgger (1921:92) påpekte, var Håkon 5. allerede som hertug engasjert i mynt- og vektstandarden i Norge. Hans første rettarbot om dette kom i 1293 og gjaldt Hedemarken og Toten. Her tar hertugen opp myntens vekt og sølvgehalt (NGL:3:19 nr. 5, pkt.10). I 1297 kom en rettarbot for Hadeland, og året etter kom en tilsvarende for Ringerike (NGL:3:29 nr.7, pkt. 5), der hertugen befalte alle å justere sine pundere (vektredskap med utgangspunkt $i$ et bismerpund) etter de steinene som var plassert i Gran, Oslo og Norderhov kirker. Den første norske kongen vi kjenner har brukt symbolet gotisk minuskel h på mynter, er nettopp Håkon Magnusson. Allerede som hertug utstedte han penninger med dette preget (Skaare 1995:2: nr. 244). Som konge fra 1299 utgav han mynt der preget opptrådte med en legende som forteller om proveniensen (Skaare 1995:2: nr. 250, 252, 253, 260). Det er i dag konsensus innen numismatikken om at myntpreget av en gotisk minuskel h identifiserer hertug og senere kong Håkon 5. Magnusson (Skaare 1997:2:190-192).

Preg kan i noen tilfeller avklare en gjenstands opphavssted. På enkelte mynter fra middelalderen viser preget hvor gjenstanden ble produsert (Skaare 1995:2:32 nr. 271, $34 \mathrm{nr}$. 288). Fra midten av 1300-tallet finnes noen få mynter preget med en h som er uten sikker proveniens. Det kan være disse myntene Grieg (1933:373) siktet til da han antydet at preget kunne representere Hamar. Myntene er brakteater; ensidig pregede små mynter hovedsakelig med ulike bokstavpreg (Skaare 1995:2: nr. 279-282, 287-290). Noen av pregene er en majuskel T, minuskel n og majuskel $\mathrm{O}$, som kan referere til utmyntingsstedene Tønsberg, Nidaros og Oslo (Skaare 1995:2:33-34). Imidlertid har én brakteatvariant en gotisk minuskel h (Skaare 1995:2: nr. 289). Dette preget kan ifølge Skaare (1995:1: nr. 89-91) bety h for Hamar, men ingen har kunnet avgjøre det med sikkerhet.

Skriftlige kilder gir et fragmentarisk innsyn i utmyntingen i Hamarkaupangen. Tre penninger fra kong Harald Hardrådes tid (1047-1066) viser en omskrift med noe variasjon. De er her referert med alle alternativene i klammer: OLAF(R)AHAM(R)(I). (Skaare 1995:2:10, nr. 6- 8). Penningenes omskrift gjør det svært sannsynlig at kong Harald Hardråde har hatt en myntmester Olaf som utstedte mynter i Hamar. Imidlertid går det 458 år til skriftlige kilder på ny knytter Hamarkaupangen til myntproduksjon. I 1524 får hamarbiskop Mogens Lauritsson rett til å slå mynt (NRR 1:4; Skaare 1995:1:99; Bakstad 2003:69), men det er ikke kjent noen mynter fra denne perioden som kan ha blitt slått i Hamarkaupangen (Skaare 1995:1:99). Vi vet ikke om biskopen fikk begynt utmynting, men i årene etter 1524 mistet 
han sine privilegier på grunn av sin motvilje mot unionskongen (NRR 1:10, 20; DN VIII 600, X 570, 574, XI 508, XXII 181). I 1531 var myntproduksjonen i Hamar igjen et tema da samme biskop allierte seg med eksilkongen Christian 2. om et statskupp mot Norge (DN VIII 629, XII 479; Bakstad 2003:101-105). Vinteren 1531-32 skal eksilkongens myntmester ha oppholdt seg i Hamar bispeborg for å slå mynt til leietroppene (Hamre 1998:479; DN VIII 671, 674, 677; Bakstad 2003:108-110). Proveniensen til myntene fra kuppforsøket er usikker. Myntene kan ha blitt slått i Oslo eller Hamarkaupangen, men verken myntpreg eller andre litterære kilder gir et entydig svar (Skaare 1995:1:101-102; Paulsen: 2016; Bakstad 2003:110). Kort oppsummert lar det seg ikke gjøre å påvise sikker utmynting i Hamarkaupangen etter Harald Hardrådes tid.

\section{Pregemetodene}

Preget av en gotisk minuskel h på vektloddene fra Hamarkaupangen forekommer i ulike utgaver. Variantene skyldes hovedsakelig at flere metoder har blitt brukt for å lage pregene. Motivet er enten gravert, innrisset, punslet eller støpt. Det er også varianter innenfor de ulike pregemetodene. De graverte motivene ble utført på to måter. Enten har man slått mange bittesmå slag mot vektloddet med en spiss utgave av et verktøy kalt punsel (punktene danner linjer i materialet og former en h), eller man har skåret ut og fjernet en del av metallet i vektloddet med en spiss gjenstand, slik at motivet ble dypere. De innrissede pregene har blitt utført ved å prege vektloddet med en skarp gjenstand. Metoden gir tynne og grunne linjer der metallet ikke blir fjernet, men forskjøvet av linjene. I de tilfeller der preget er punslet, har man først gravert en h i enden av en punsel, med et speilvendt motiv. Deretter satte man punselen mot vektloddets overflate og slo ett slag på den slik at gjenstanden under ble preget. Denne metoden ble brukt ved produksjon av stempel til mynter, noe som forenklet serieproduksjonen av identisk preg på mange gjenstander. En fjerde måte var å lage et preg i en støpeform. Alle vektlodd som ble støpt i denne formen, fikk da identisk form og

Bilde 3 Platevektlodd med preg av gotisk minuskel $h$ på et våpenskjold. Gjenstand HKH-05626. Foto: G.O.A. Anno Domkirkeodden.

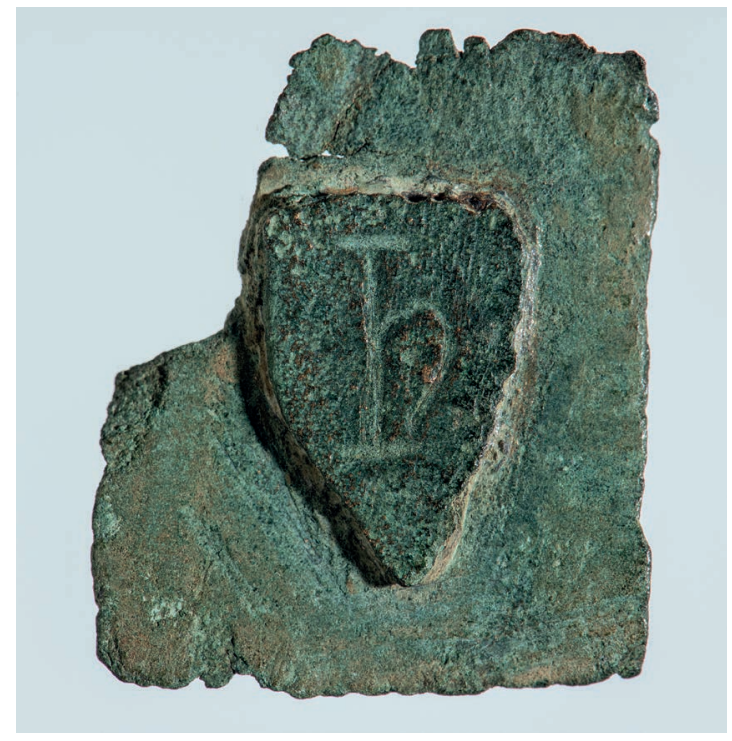




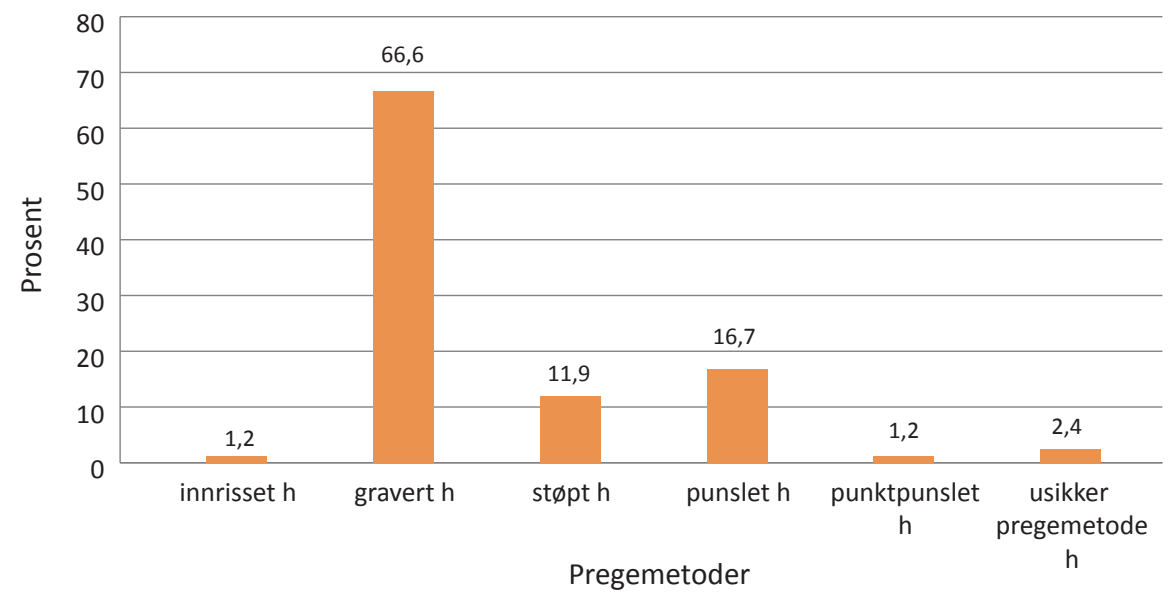

Diagram 5 Fordeling av preget gotisk minuskel hi \% etter pregemetode. Statistikk: A.K.

Bakstad 2019.

preg. Også denne fremgangsmåten åpner for serieproduksjon (Erik Bjørnstad, personlig kommunikasjon 20.08. 2018). Alle disse metodene er brukt for å prege en h i vektloddene fra Hamar.

Innrissing, gravering og punktpunsling er pregemetoder der hvert preg blir utformet individuelt, og gjelder til sammen $69 \%$ av h-pregene i samlingen (diagram 5). De støpte og punslede pregene tilsier serieproduksjon av identiske preg. Det at 28,6 \% av h-pregene er utført med metoder som forbindes med serieproduksjon, sannsynliggjør at langt flere gjenstander fikk nøyaktig samme preg. Med punslene er det selve preget som serieproduseres, mens ved støping serieproduseres både preg og vektlodd. Hvis serieproduksjon ikke hadde vært formålet, er det svært lite sannsynlig at man hadde brukt tidkrevende metoder for å gravere en punsel eller lage en støpeform. De to metodene forteller derfor at nær $30 \%$ av vektloddenes h-preg er resultat av planlagt eller organisert preging av dette symbolet på mange vektlodd.

Svært mange av vektloddenes utgaver av preget gotisk minuskel $\mathrm{h}$ inneholder noe som kan se ut som en prikk. Denne er ofte plassert mellom beina på bokstaven $h$. En tilsvarende prikk gjenfinnes som nevnt på mynter med preg av en gotisk minuskel h fra kong Håkon 5.s tid (Skaare 1995:2: nr. 260). I numismatikken kalles dette en «senterprikk». Den ble plassert midt på den sirkulære overflaten til et myntstempel, før man graverte stempelet. Senterprikken skulle hjelpe gravøren med å sentrere preget (Erik Bjørnstad, personlig kommunikasjon 25.11. 2018). På vektloddene har man ikke hatt det samme behovet for å sentrere preget, ettersom det ble satt på gjenstander og overflater av ulik form og størrelse. I tillegg er pregene på vektlodd utført med hele fem ulike pregeteknikker. Senterprikken sees også på individuelt utformede h-preg. Videreføringen av senterprikken fra myntenes offisielle kongemonogram til vektloddenes ulike preg av h mer enn antyder at myntpreg med kong Håkon 5. Magnussons monogram må ha vært forelegg for de h-pregene vi finner på vektloddene fra Hamarkaupangen. 


\section{Lokal vektloddproduksjon}

Gjenstandssamlingene fra Hamarkaupangen dokumenterer et omfattende metallhåndverk (Grieg 1941; Sæther 1990, 1994, 2006, 2015; Dahlerup Koch 1991; Færden 1991,1995; Nyquist 1995; Bakstad 2015). Majoriteten av samlingen består av gjenstander og verkstedsavfall i kobberlegering. I tillegg til tusenvis av metallgjenstander er det påvist smelteavfall fra støping i kobberlegeringer, bly og sølv. De utallige avklippene av kobberplater, metalltråder og støpetapper indikerer at Hamarkaupangens håndverkere har arbeidet med en variert gjenstandsproduksjon i ulike metaller og bearbeidingsteknikker.

Et sentralt spørsmål er om de mange vektloddene representerer gjenstandstyper som ble produsert i Hamarkaupangen. Stedlig vektloddproduksjon kan påvises om gjenstandssamlingen skulle inneholde uferdige vektlodd eller redskaper knyttet til vektloddproduksjon. Blant gjenstandsfunn som representerer produksjon av vektlodd så vel som andre gjenstandstyper i metall, er råvarer i form av 19 metallbarrer. De fordeler seg på ni i kobber, seks i bly, to i sølv, én i tinn og én i blyholdig tinn. Av smedverktøy finnes det fire små hammere, to støpeskjeer, to ambolter samt to støpeformer. De to støpeformene er i sandstein og kleberstein, og har hulrom til henholdsvis et segment, altså en halvkuleformet gjenstand, samt en kuleformet gjenstand uten to poler (HKH-03996, HKH-14202). Støpeformen til den halvkuleformede gjenstanden kan ha blitt brukt til produksjon av segmentformede vektlodd

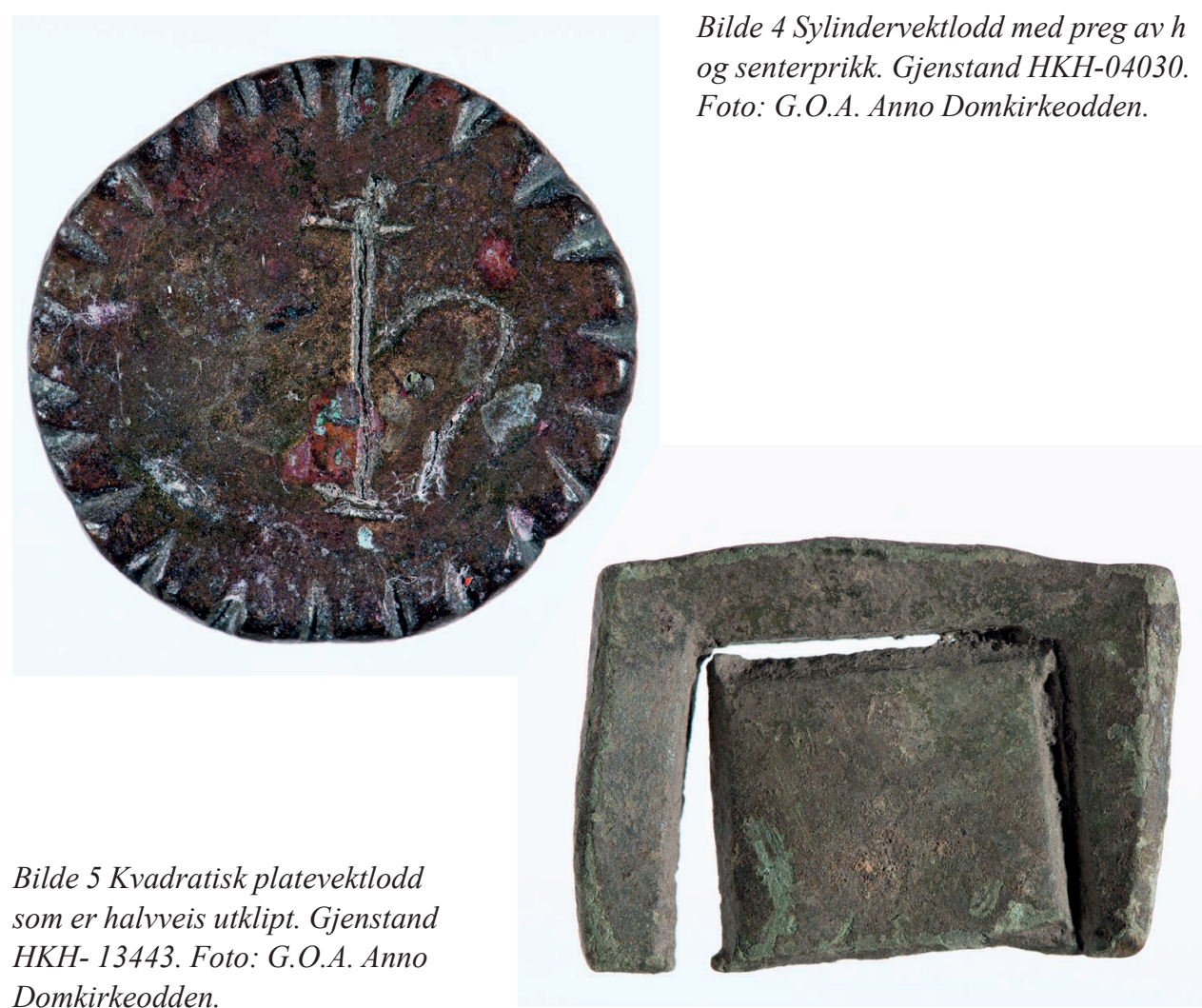


ettersom formen er for stor til knappestøping. Det er likevel ikke avklart hvilken gjenstandstype som har blitt støpt i formen. Det finnes også en godt bevart smeltedigel av kobberlegering fra Hamarkaupangen (HKH-11210). Den har et flott, punslet preg av en omvendt gotisk minuskel h på siden, av samme type som de vi finner på vektlodd (sikre preg: HKH-05576, HKH-11103, HKH-13575, HKH-13668, samt et sannsynlig preg: HKH-07404). Et annet viktig gjenstandsfunn er et halvveis utklipt platevektlodd i kobberlegering (HKH-13443). I tillegg finnes utallige mengder av små, tilklipte metallplater i kobberlegering, som kan være emner til de minste platevektloddene vi kjenner fra Hamarkaupangen.

På bakgrunn av disse funnene er det svært sannsynlig at platevektlodd i kobberlegering har blitt produsert i Hamarkaupangen. I den grad støpeformene kan knyttes til produksjon av vektlodd, vil også støpte vektlodd kunne være en del av gjenstandsproduksjonen. Den intakte smeltedigelen med preg av en omvendt gotisk minuskel h står i en særstilling. Det er grunn til å tro at samme prinsipp må gjelde for preget på smeltedigelen som for andre gjenstander hvor dette motivet befinner seg. Ettersom en preget gotisk minuskel h er et offentlig symbol som representerer kong Håkon 5, må dette gjelde også når symbolet forekommer på en smeltedigel. I dette tilfellet gir det liten mening å tenke at det er selve gjenstanden som er blitt godkjent med et offentlig justeringsmerke, ettersom den er et redskap brukt til å håndtere flytende metaller ved støpeprosesser. Imidlertid kan eieren av verktøyet ha hatt en

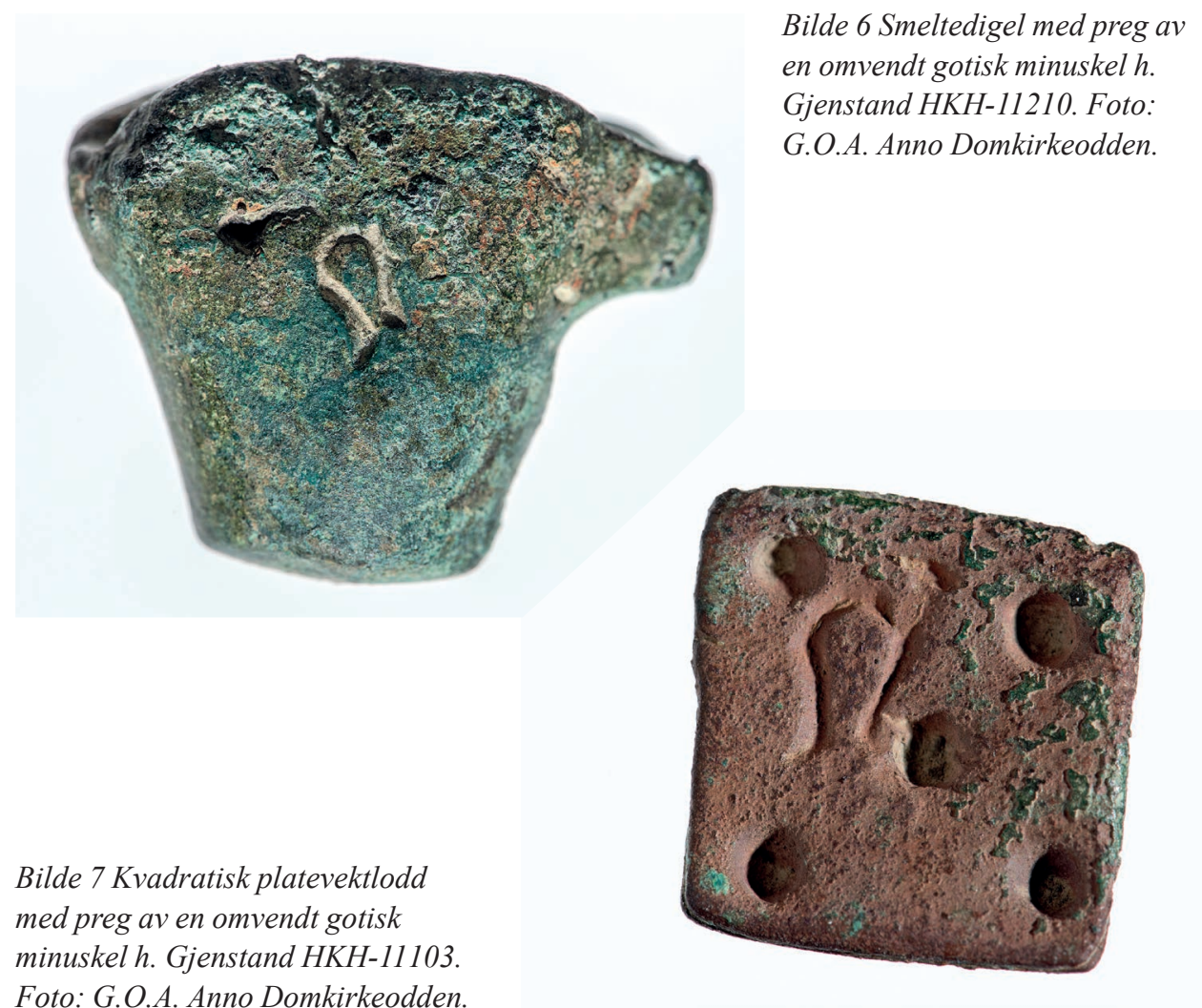


offentlig godkjenning eller rolle i produksjonen av støpte og offentlig justerte gjenstander. Preget av en gotisk minuskel h både på smeltedigelen og på støpte gjenstander i vektloddsamlingen fra Hamarkaupangen gjør det nærliggende å tro at det kan ha foregått en offentlig godkjent vektloddproduksjon, som inneholdt støpte så vel som hamrede platevektlodd.

\section{Oppsummering:}

Vektloddsamlingen fra Hamarkaupangen utgjør en betydelig andel av de vektloddene fra middelalderen som er registrert i Norge. Samlingen består av 10 vektloddtyper som antyder at gjenstandssamlingen kan ha sitt tyngdepunkt fra 1100-tallet og opp gjennom middelalderen. Det sammenfaller med etableringen av Hamar bispesete i Hamarkaupangen i 1152 . Majoriteten av vektloddene fra Hamarkaupangen er laget i kobberlegering. Plate- og skjoldvektloddene er de mest tallrike typene fra Hamar, mens de samme typene i mindre grad ser ut til å være representert i det øvrige vektloddmaterialet på landsbasis.

8 av 10 vektloddtyper fra Hamarkaupangen inneholder gjenstander med preg av en gotisk minuskel h. Preget opptrer på 78 av totalt 313 vektlodd. Vektloddenes h-preg viser seg å være identiske med kong Håkons 5.s monogram, som han brukte både som hertug fra 1273 og som konge i 1299 - 1319. Selv om h-preget på vektloddene har blitt utført med fire ulike pregemetoder, avslører detaljene i pregene at kongemonogrammet på Håkon 5.s mynter er brukt som forelegg for h-preget på vektloddene. Nær $30 \%$ av alle h-pregene på vektloddene har blitt utført med metoder som forbindes med serieproduksjon av identiske preg. På samme sted er det funnet preg av en h på verktøy som ble brukt i forbindelse med metallstøping. Det er også påvist at vektloddproduksjon har foregått i Hamarkaupangen.

Skriftlige kilder viser at Håkon 5. var opptatt av å få kontroll med vektstandarden. De mange pregene av h på vektloddene og metallhåndverkerens verktøy i Hamarkaupangen åpner for den tolkning at det har foregått både vektloddproduksjon og merking av offentlig justerte vektlodd i Hamarkaupangen i Håkon 5.s tid som hertug og konge. I så fall viser de 78 vektloddene med preg av en gotisk minuskel h at vektlodd har fått en ny rolle som representanter for en offentlig justert vektstandard i kong Håkon 5.s tid.

Studiene av middelalderens vektlodd i Norge er få. En videre forskning på Hamarkaupangens vektloddmateriale og middelalderens vektlodd generelt er nødvendig for å få en oversikt over denne type vektredskaper. Vi har i dag ingen vektloddtypologi eller kronologi over middelalderens vektlodd verken i Norge eller i Skandinavia. En dypere analyse av vektsystemet som loddene var en del av, er også nødvendig. Samtidig ligger det et stort, innholdsrikt og uavklart kildegrunnlag i det å forstå betydningen av de mange pregene som finnes på denne type gjenstandsmateriale fra middelalderen.

\section{Takk}

Jeg ønsker å takke kolleger på Anno Domkirkeodden, Kristian Reinfjord for faglige bidrag og innspill til artikkelen, Erik Bjørnstad og Tor Sæther for deling av sine store kunnskaper om Hamarkaupangen, fotograf Geir Ove Andreassen for foto og filbehandling, samt Ranveig Nordbryhn for korrektur på engelsk tekst. Jeg vil også rette en stor takk til Birgit Maixner og Jenny Kalseth ved Vitenskapsmuseet, NTNU for stor velvilje og hyggelig tilrettelegging for studier av vektloddmaterialet i magasinet i Trondheim. 


\section{Litteraturliste}

Ahlström, Bjarne, Bernhard F. Brekke, Bengt Hemmingsson

1976 Norges Mynter - The Coinages of Norway. Det numismatiska bokförlaget AB. Stockholm.

Bakstad, Anne Kathrine

2003 Mogens Lauritsson, riksråd og biskop 1513-1537. Hovedfagsoppgave i historie, Historisk institutt NTNU. Trondheim.

2015 Middelalderens merkevarer: vareplombene fra Hamarkaupangen. I Anno Hedmark, redaktør Harald Jacobsen:215-244. Museumsforlaget.

Brøgger, Anton Wilhelm

1921 Ertog og øre: den gamle norske vegt. Videnskapsselskapets skrifter II. Hist.-filos. Klasse. 1921, nr. 3. Dybwad, Kristiania.

1936 Mål og vekt i forhistorisk tid i Norge. Nordisk Kultur XXX Maal og Vaegt, redigert av Svend Aakjær: 75-83. Stockholm.

Diplomatarium Norvegicum

1847-2011 Diplomatarium Norvegicum. Oldbreve til Kundskab om Norges indre og ydre Forhold, Sprog, Slcegter, Sceder, Lovgivning og Rettergang i Middelalderen, Bind 1-23. Elektronisk dokument. http://www.dokpro.uio.no/dipl_norv/diplom_felt.html, besøkt 15. oktober 2018.

Færden, Gerd

1991 Serieproduserte håndverksprodukter fra Storhamarstranda. I Fra kaupang og bygd 1991: 21-36. Hedmarksmuseet og Domkirkeodden. Hamar.

1995 Bokbeslag fra Storhamarstranda, I Fra kaupang og bygd 1995: 91-101. Hedmarksmuseet og Domkirkeodden. Hamar.

Grieg, Sigurd

1933 Middelalderske byfund fra Bergen og Oslo, A.W.Bröggers boktrykkeri A/S, Oslo.

1941 Byfunnene på Stor-Hamar. I Hedmarksmuseet og Domkirkeodden Hamar, Arsmelding 193941:3-19. Norsk Skoletidendes Boktrykkeri. Hamar.

Gustin, Ingrid

1997 Islam, Merchants or King? Who was behind the Manufacture of Viking Age Weights? I Visions of the Past. Trends and Traditions in Swedish Medieval Archaeology, redigert av H. Andersson, P. Carelli, og L. Ersgård. Lund studies in Medieval Archaeology 19. Riksantikvarieämbetet, Arkeologiska Undersökningar, Skrifter nr. 24:163-177. Riksantikvarieämbetet og Lunds Universitet. Stockholm.

Hamre, Lars

1998 Norsk politisk historie 1513-1537. Det Norske Samlaget. Oslo.

Huitfeldt-Kaas, Henrik Jørgen

1899 Norske Sigiller fra Middelalderen. Udgivne efter offentlig foranstaltning. Første og Andet Hefte. Bind 1. Aktie-Bogtrykkeriet. Kristiania.

Holmboe, Christopher Andreas

1863 Norske Vaegtlodder fra Fjortende Aarhundrede, Brøgger \& Christie, Christiania.

Dahlerup Koch, Hanne

1991 Resultater fra de arkeologiske utgravningene på kirkegården omkring domkirkeruinen på Hamar. I Fra kaupang og bygd 1991:15-20. Hedmarksmuseet og Domkirkeodden. Hamar.

Kulturhistorisk leksikon for nordisk middelalder fra vikingetid til reformasjonen 1982[1975] Bind 19: 2. oplag, Rosenkilde og Bagger. Købehavn.

Kyhlberg, Ola

1973 Viktlod. I Birka, Svarta Jordens hamnområde, arkeologisk undersökning 1970-71. Riksantikvarieämbetes rapport C1, redigert av B.Ambrosiani, B. Arrhenius, K.Danielsson, O. Kyhlberg og G.Werner: 207-215. Riksantikvarieämbetet, Stockholm.

1980a Vikt och värde: Arkeologiska studier $i$ värdemättning, betalingsmedel och metrologi under yngre järnålder. I Helgö. II Birka. Stockholm. 
1980b Helgö och Birka. Kronologisk-topografisk analys av grav- och boplatser. Arkeologiska rapporter och meddelanden från Institutionen för Arkeologi, särskilt nordeuropeisk, vid Stockholms Universitet, nr. 6.

Mikkelsen, Egil

1996 Arabisk sølv og Nordens guder. Islam i vikingtid. I Fra hedendom til kristendom. Perspektiver på religionsskiftet i Norge, redigert av Magnus Rindal:31-43. Ad Notam Gyldendal AS. Oslo.

Norges Gamle Love

1848 Norges gamle Love indtil 1387. Andet Bind: Lovgivningen under Kong Magnus Haakonssøns Regjeringstid fra 1263 til 1280, tilligemed et Supplement til første Bind. Utgitt av R. Keyser og P.A. Munch. Det kongelige Norske Videnskabers Selskab, Christiania.

1849 Norges gamle Love indtil 1387. Tredie Bind: Lovgivningen efter kong Magnus Haakonssøns Død 1280 indtil 1387. Utgitt av R. Keyser og P.A. Munch. Det kongelige Norske Videnskabers Selskab, Christiania.

Norske Rigs-Registranter

1861 Norske Rigs-registranter: tildeels i Uddrag: B.1: 1523-1571, utgitt av Christian C.A. Lange med bistand af Edvard O.Heiberg og Siegwart Petersen. Christiania.

Nyquist, Brita

1995 Middelaldersegl og stamper fra Hamarkaupangen. I Fra kaupang og bygd 1995: 102-113. Hedmarksmuseet og Domkirkeodden. Hamar.

Paulsen, Erik O.

2016 Penger i Norge. Elektronisk dokument, https://snl.no/Penger_i_Norge, bes økt 15. januar 2019.

Pedersen, Unn

2000 Vektlodd-Sikre vitnesbyrd om Handelsvirksomhet? Vektloddenes funksjoner i Vikingetid. En analyse av vektloddmaterialet fra Kaupang og sørøst-Norge. Hovedfagsoppgave i nordisk arkeologi. IAKK: Hist.fil. fakultet. Universitetet i Oslo.

2008 Weights and balances. I Means of Exchange. Dealing with Silver in the Viking Age. Kaupang Excavation Project Publication Series, vol.2. Norske Oldfunn XXIII, kap.6: s. 119-195. Aarhus University Press. Århus.

2010 I smeltedigelen: Finsmedene i vikingtidens Kaupang. Avhandling ph.d. Institutt for arkeologi, konservering og historie, Det humanistiske fakultetet, Universitetet i Oslo.

Petersen, Jan

1934 Handel i Norge i vikingtiden. I Nordisk Kultur XVI. A. Handel og samfcerdsel i Oldtiden.: 39-48. J. Brøndsted, København.

Ramberg, Linn Eikje

2017 Mynt er hva mynt giør. En analyse av norske mynter fra 1100-tallet: produksjon, sirkulasjon og bruk. Avhandling ph.d. Humanistiska fakulteten, Institutionen för arkeologi och antikens kultur, Stockholms universitet.

Skaare, Kolbjørn

1995 Norges mynthistorie, bind 1 og 2, Universitetsforlaget. Oslo.

Sperber, Erik

1996 Balances, weights and weighing in ancient and early medieval Sweden. Theses and papers in scientific Archaeology 2. Archaeological Research Laboratory. Stockholm University.

Steinnes, Asgaut

1936 Mål, vekt og verderekning i millomalderen og ei tid etter. I Nordisk kultur XXX, redigert av Svend Aakjær: 84-134. H. Aschehoug og Cos forlag. Oslo.

Steuer, Heiko

1997 Waagen und Gewichte aus dem mittelalterlichen Schleswig: Funde des 11. bis 13. Jahrhunderts aus Europa als Quellen zur Handels- und Währungsgeschichte. Rheinland-Verlag GmbH, Köln.

Sæther, Tor

1990 Et nyutgravd stykke av Hamars middelalder. I Fra kaupang og bygd 1990: 7-28.

Hedmarksmuseet og Domkirkeodden. Hamar. 
1994 Gjenstandsfunn forteller om Hamarkaupangen. I Fra kaupang og bygd 1994:83-110. Hedmarksmuseet og Domkirkeodden. Hamar.

2006 Sykdom og død i det gamle Hamar. I Fra kaupang og bygd 2006: 62-74. Hedmarksmuseet og Domkirkeodden. Hamar.

2015 På sporet av metallhåndverk i Hamarkaupangens omland, I Anno Hedmark, redaktør Harald Jacobsen:189-214. Museumsforlaget.

Unimus

Universitetsmuseenes samlinger på nett. De arkeologiske samlingene.

http://www.unimus.no/arkeologi/forskning/index.php Besøkt 10. januar 2019. 